\title{
SECtion 116 Of the Australian CONSTITUTION AND DRESS RESTRICTIONS
}

\section{ANTHONY GRAY*}

This article considers constitutional arguments that would arise if a government at either federal or state level decided to ban dress often identified as having religious connotations. This is not a far-fetched scenario, with at least one current Member of Parliament calling for such a ban, and bans operating in some overseas jurisdictions. It concludes that there would be serious constitutional doubt about such a law.

\section{INTRODUCTION}

The question of the extent to which an individual has or should have the right to religious freedom, and to manifest that freedom by wearing particular items of clothing, is very contentious. Some nations have banned the wearing of particular items of clothing thought to have religious significance, at least in some contexts. Courts from a range of jurisdictions have been asked to resolve these issues, involving a range of values and competing interests. As we will see, they have done so in different ways, and some of the results are, at first glance, somewhat surprising.

In this article, I will consider constitutional (and discrimination) issues that would arise if an Australian parliament enacted legislation with the effect, amongst other things, of prohibiting the wearing of particular items of clothing often thought to have religious significance, in particular the hijab, burqa or niqab. While the ban could apply to other items of clothing or

\footnotetext{
* Professor, Deputy Head, University of Southern Queensland Law School.

${ }^{1}$ The hijab is taken to refer to a head covering traditionally worn by Muslim women (the word can also be used to explain modest Muslim styles of dress in general), the burqa is a full dress covering a woman's body, including a veil over the woman's face (this veil is separately referred to as a niqab). I will explain my proposed law in more depth later, but in essence it would prohibit the covering of the face whilst in public, with clear signals that the law was
} 
jewellery of significance in religions other than Islam, given that most of the current debate concerns symbols of Islam, I will use this particular context as the focus of discussion. In so doing, I will draw briefly upon the rich jurisprudence concerning these issues in other jurisdictions, where much more litigation has taken place regarding the question than in Australia. I will also consider briefly whether a different result would apply if the ban were passed at state level. This is not an abstract argument; a current Senator in the Australian parliament has personally called for a burqa ban, and private members' bills have been introduced in New South Wales and South Australia to introduce such a ban, at least in some circumstances.

In Part II I set the statutory framework for the discussion that follows. In Part III the meaning of the wearing of the hijab and burqa is considered. Part IV considers how laws banning the wearing of religious dress or symbols have been considered in various courts. In Part V I consider the validity of a Commonwealth law that had the effect of banning the wearing of some religious dress or symbols.

\section{Statutory Context OF Freedom of ReLigion}

Section 116 of the Commonwealth Constitution forbids the Commonwealth parliament to pass a law establishing a religion, imposing a religious observance, or prohibiting the free exercise of religion, and forbids a religious test to be required as a qualification for office in the Commonwealth. ${ }^{2}$ It is based on the American anti-establishment clause found in the First Amendment, and Article VI section 3, regarding the permissibility of religious tests in order to take office. No law has ever been struck down as being offensive to the section 116 prohibition. The prohibition applies (expressly) only to Commonwealth laws, not state laws.

The right to freedom of religion is recognised as fundamental in various international human rights documents. These include Article 9(1) of the European Convention on Human Rights, protecting the right to freedom of religion and to manifest that religion in worship or practice, subject to limited exceptions. ${ }^{3}$ It is clear that 'practice' here includes the wearing of distinctive

passed with Islamic-style dress in mind. This reflects the kind of law passed in some countries where a ban exists - on its face, neutral, but with Islam in mind.

${ }^{2}$ See also Human Rights Act 2004 (ACT) s 14 and Charter of Rights and Responsibilities Act 2006 (Vic) s 3. Section 46 of the Tasmanian Constitution provides for free profession and practice of religion 'subject to public order and morality': Constitution Act 1934 (Tas).

${ }^{3}$ Article 9(2) provides for limits to the freedom if they are prescribed by law and necessary in a democratic society in the interests of public safety, protection of the public order, to protect 
clothing or head covering. ${ }^{4}$ Very similar provisions appear in Article 18 of the International Covenant on Civil and Political Rights, and Article 18 of the Universal Declaration of Human Rights. It has been suggested that freedom of religion and conscience are the oldest of the internationally recognised human rights. ${ }^{5}$ This might reflect a long history of violence and persecution in relation to religion, oppression of religious minorities, imposition of religion by states and so forth. As the United States Supreme Court noted:

A large proportion of the early settlers of this country came here from Europe to escape the bondage of laws which compelled them to support and attend government favored churches. The centuries immediately before and contemporaneous with the colonization of America had been filled with turmoil, civil strife, and persecutions, generated in large part by established sects determined to maintain their absolute political and religious supremacy. ${ }^{6}$

The rise of these particular rights may also have been a response to the historical view that the monarch, in whom lawmaking functions were reposed, was the representative of a higher religious authority. Links with theories of natural law may be acknowledged here. The present separation of religion and state stands in great contrast to the historical position of the monarch as lawmaker and religious figure. ${ }^{7}$

Despite these provisions, ${ }^{8}$ some jurisdictions have recently moved to ban

health or morals, or to protect the rights and freedoms of others. Related rights include the right to respect for private and family life (art 8), right to freedom of expression (art 10), the right to freedom from discrimination on the basis of religion (art 14), and the right to education (art 2 of the First Protocol). The interpretation of these limits must be strict, and limits must be directly related and proportional to the specific need; they must not be applied in a discriminatory manner: United Nations Human Rights Committee, 'General Comment No 22: The Right to Freedom of Thought, Conscience and Religion (Art 18)' (48 ${ }^{\text {th }}$ sess, 1993). The European Court has found that restrictions on religious freedom call for 'very strict scrutiny' by the Court since the right is fundamental in nature: Manoussakis $v$ Greece (1997) 23 EHRR 387, 407.

${ }^{4}$ United Nations Human Rights Committee, 'General Comment 22: The Right to Freedom of Thought, Conscience and Religion (Art 18)' (48 ${ }^{\text {th }}$ sess, 1993).

${ }^{5}$ W Cole Durham Jr, 'Freedom of Religion: The United States Model' (1994) 42 American Journal of Comparative Law 617, 618; Abdullah Saeed and Hassan Saeed, Freedom of Religion, Apostasy and Islam (Ashgate Publishing, 2004) 10.

${ }^{6}$ Everson v Board of Education 330 US 1 (1947).

${ }^{7}$ Great advocates for religious freedom in the past have included John Stuart Mill, On Liberty (1859) 51-2 and John Locke, A Letter Concerning Toleration (1689).

${ }^{8} \mathrm{M}$ Todd Parker argues that legal precedents allowing restrictions on religious dress and other practice are often not faithful to the requirements of the International Covenant and European Covenant on Human Rights: 'The Freedom to Manifest Religious Belief: An Analysis of the 
some forms of religious expression. ${ }^{9}$ As one example for discussion purposes, the French Law 2004-228 prohibits in Article 1, in public elementary schools, colleges, junior high schools and high schools, the wearing of signs and behaviours by which the pupils express openly a religious membership. On its face the Article does not single out a particular religion; however in practice it has been applied almost exclusively to require that the hijab and burqa not be worn at these venues. ${ }^{10}$ In 2010, the French government moved to extend the ban beyond educational settings.

\section{Meaning of the HiJAB ANd BURQA}

The fundamental question arises as to whether a law with the effect of banning the hijab and burqa interferes with the person's right to freedom of religion, and their right to manifest that religion in practice. It is necessary to refer to religious documents, as well as views as to the symbolism of such dress, in order to answer this question.

Important sources of information in answering this question are the relevant provisions of the Koran (Qur'an) itself. Typically, the following passage is quoted:

And say to the believing women that they should lower their gaze and guard their modesty; that they should not display their beauty and ornaments except what (must ordinarily) appear thereof; that they should draw their veils over their bosoms and not display their beauty except to their husbands, their fathers, their husband's fathers, their sons, their brothers or their brother's sons, or their women. ${ }^{11}$

Necessity Clauses of the ICCPR and the ECHR' (2007) 17 Duke Journal of Comparative and International Law 91.

${ }^{9}$ Links with post 9-11 hysteria have been noted here: 'women who are readily identified as Muslim because they wear a headscarf or veil report that they have often been the target of racist violence and discrimination and that this increased post 9-11 as their clothing is now read to signify religious fundamentalism, danger and terrorism': Margaret Thornton and Trish Luker, 'The Spectral Ground: Religious Belief Discrimination' (2009) 9 Macquarie Law Journal 71, 83.

${ }^{10}$ Mark A Levine reports that in the first year following the passage of the French law, 47 Muslim girls had been expelled from French schools for wearing the hijab: 'The Modern Crusade: An Investigation of the International Conflict between Church and State' (2009) 40 California Western International Law Journal 33, 42.

${ }^{11}$ Qur'an 24: 30-31, 24: 60, 33: 59 and 33: 53; Abdullah Yusuf Ali, The Qur'an: Text, Translation and Commentary (Tahrike Tarsile Qur'an, 2001) 904-5. 
As with many issues in religion, the above passage has been interpreted in different ways. A specific challenge with Islam is that, as Baker notes, there is no central authority figure, with the result that followers adhere to different forms and interpretations of Islamic tenets. ${ }^{12}$ Opinions differ as to what 'guarding their modesty' might mean; some interpret this strictly to require that the full body garment (burqa) be worn; others see the headscarf as being sufficient; others argue that the woman merely cannot wear clothing showing the outline of her bosom. ${ }^{13}$ Others say that the headscarf is a cultural tradition that has nothing to do with Islam, and the hijab referred to in the Qur'an is a curtain Muhammad used to separate his wives from male visitors, and is not a piece of clothing at all. ${ }^{14}$

There have been other suggestions as to the significance of the hijab or burqa that are based on culture rather than religion per se. Tiefenbrun summarises these as including the facts that:

It is a positive symbol designating the cultural and religious source of protection, respect and virtue;

It is a positive sign signifying Muslim identity, which might (arguably) be seen as opposition to Western civilisation;

It is a positive sign allowing Muslim women to freely participate in public life, preventing women from 'tempting men and corrupting morality'; $; 5$

\footnotetext{
${ }^{12}$ Christina Baker, 'French Headscarves and the US Constitution: Parents, Children and Free Exercise of Religion' (2008) 13 Cardozo Journal of Law and Gender 341, 359.

${ }^{13}$ Mukul Saxena, 'The French Headscarf Law and the Right to Manifest Religious Belief' (2007) 84 University of Detroit Mercy Law Review 765, 779-80; Susan W Tiefenbrun, 'The Semiotics of Women's Human Rights in Iran' (2007) 23 Connecticut Journal of International Law 1, 25; T Jeremy Gunn, 'Religious Freedom and Laïcité: A Comparison of the United States and France' (2004) 2 Brigham Young University Law Review 419, 471; Robert Kahn, 'The Headscarf as Threat: A Comparison of German and US Legal Discourses' (2007) 40(2) Vanderbilt Journal of Transnational Law 417, 438.

${ }^{14}$ Gunn, above $n$ 13, 471-2.

${ }^{15}$ Aliah Abdo, 'The Legal Status of Hijab in the United States: A Look at the Sociopolitical Influences on the Legal Right to Wear the Muslim Headscarf' (2008) 5 Hastings Race and Poverty Law Journal 441, 441, 449: 'Hijab is not only meant to guard women from inappropriate leering male attention, but it is considered to be a liberating experience to be free from societal expectations and judgments over a women's body and other physical characteristics'; Mark A Levine, 'The Modern Crusade: An Investigation of the International Conflict Between Church and State' (2009) 40 California Western International Law Journal 33,41 . Writing of the Iranian position, Susan W Tiefenbrun claims that 'women in Iran today are no longer excluded from public life and politics, and their participation has in fact increased in some areas due to, and not in spite of, the compulsory wearing of the veil or
} 
It is a negative symbol of Islam's power over women. ${ }^{16}$ (Badinter concurs, claiming that the veil 'is the symbol of the oppression of a sex ... [P] utting a veil on the head, this is an act of submission. It burdens a woman's whole life'.) ${ }^{17}$

Some studies based on interviews with Muslim women suggest that, while some Muslim women adopt the veil to comply with family values and expectations, it is becoming more common that women choose to wear the headscarf themselves, often without pressure and often against their parents' wishes. It is sometimes argued by Muslim women that the veiling forces males to deal with them on a mental level as equals, rather than sexual

hijab': 'The Semiotics of Women's Human Rights in Iran' (2008) 23 Connecticut Journal of International Law 1, 19.

${ }^{16}$ Susan W Tiefenbrun, 'The Semiotics of Women's Human Rights in Iran' (2008) 23 Connecticut Journal of International Law 1, 22-3; Stefanie Walterick, 'The Prohibition of Muslim Headscarves from French Public Schools and Controversies Surrounding the Hijab in the Western World' (2006) 20 Temple International and Comparative Law Journal 251, 255: 'to many people in France, the hijab is also a symbol of the oppression and subjugation of Muslim women'; Stasi Commission, 'Commission de Réflexion sur l'Application du Principe de Laïcité dans la République: Rapport au Président de la République' (Stasi Commission Report, December 2003) 46-8; Christopher D Belelieu, 'The Headscarf as a Symbolic Enemy of the European Court of Human Rights' Democratic Jurisprudence' (2006) 12 Columbia Journal of European Law 573, 583: 'just like Islam itself, the practice of veiling can take on a range of styles and meanings ... (619) the message conveyed (by the wearing of the veil) depends on the carrier of the symbol as well as the audience of that symbol'; Adrien Wing and Monica Smith, 'Critical Race Feminism Lifts the Veil?: Muslim Women, France and the Headscarf Ban' (2006) 39 University of California Davis Law Review 743, 746-7, 750-1. Chouki El Hamel argues the hijab ensures that men will maintain their status as providers and guardians of women and ensures that women remain isolated: 'Muslim Diaspora in Western Europe: The Islamic Headscarf (Hijab), the Media and Muslims' Integration in France (2002) 6(3) Citizenship Studies 293, 302; Ghais Jasser, 'The Twin Evils of the Veil' (1999) 5 Social Identities 31, 37: 'the veiled woman is reduced to impotence'.

${ }^{17}$ Elisabeth Badinter, Interview with L Joffin (Le Nouvel Observateur (9-15 November 1989) 7-11; Nilufer Gole, 'The Voluntary Adoption of Islamic Stigma Symbols' (2003) 70(3) Social Research 809, 817-18; Azar Majedi denounces the veil as 'the ideological banner of Iran's sexual apartheid and misogynist values': Women's Rights vs Political Islam: A Series of Political Writings About the Devastating Effects of Political Islam on Women's Situation and the Struggle of Women Against It (Medusa-huset, 2007); Steven G Gey, 'Free Will, Religious Liberty, and a Partial Defense of the French Approach to Religious Expression in Public Schools' (2005) 42 Houston Law Review 1, 62: 'In France, the government is seeking to create a limited area in which especially vulnerable students are free to consider all areas and possibilities, free from the constraints imposed by them by the religions and social mandates of their community and family'. Cf Aliah Abdo who describes these views as a 'severely flawed and false reflection of Islamic principles': 'The Legal Status of Hijab in the United States: A Look at the Sociopolitical Influences on the Legal Right to Wear the Muslim Headscarf' (2008) 5 Hastings Race and Poverty Law Journal 441, 441. 
objects. ${ }^{18}$ Economics may even play a role. ${ }^{19}$ A multitude of reasons is plausible. ${ }^{20}$ Baroness Hale engages with the complex symbolism of the wearing of religious dress such as the hijab or burqa in her judgment in $R v$ Headteacher and Governors of Denbigh High School, quoting Yasmin Alibhai-Brown:

What critics of Islam fail to understand is that when they see a young woman in a hijab she may have chosen the garment as a mark of her defiant political identity and also as a way of regaining control over her body. ${ }^{21}$

As Choudhury summarises it, 'Islamic scholars and feminists continue to debate whether hijab is compulsory and, if so, what practices of dress constitute valid observance. ${ }^{22}$

Given this range of views, it would be difficult for a court to determine emphatically that the wearing of the hijab or burqa either was, or was not, a manifestation of a religious practice. The courts have sometimes expressed their reluctance to judge the 'validity' of an asserted religious belief, acknowledging that religious belief is intensely personal:

[E]mphatically, it is not for the court to embark upon an inquiry into the asserted belief and judge its validity by some objective standard such as the source material upon which the claimant founds his belief or the orthodox teaching of the religion in question or the extent to which the claimant's

\footnotetext{
${ }^{18}$ Adrien K Wing and Monica Nigh Smith, 'Critical Race Feminism Lifts the Veil?: Muslim Women, France and the Headscarf Ban' (2006) 39 University of California Davis Law Review $743,761-3$. Others note that in other cultures, such as the Berber-speaking Tuareg of West Africa, men veil, and masks are common in other cultures, which has not attracted the same controversy as that of a woman veiling: John Borneman, 'Veiling and Women's Intelligibility' (2009) 30(6) Cardozo Law Review 2745, 2748-9.

${ }^{19}$ Dina Alsowayel, 'The Elephant in the Room: A Commentary on Steven Gey's Analysis of the French Headscarf Ban' (2006) 42 Houston Law Review 103, 118.

${ }^{20}$ T Jeremy Gunn, 'Commentary: French Secularism as Utopia and Myth' (2005) 42 Houston Law Review 81, 98; Yael Barbibay, 'Citizenship Privilege or the Right to Religious Freedom: The Blackmailing of France's Islamic Women (2010) 18 Cardozo Journal of International and Comparative Law 159, 201; Karima Bennoune, 'Secularism and Human Rights: A Contextual Analysis of Headscarves, Religious Expression and Women's Equality Under International Law' (2007) 45 Columbia Journal of Transnational Law 367, 388; Christopher D Belelieu, 'The Headscarf as a Symbolic Enemy of the European Court of Human Rights' Democratic Jurisprudence: Viewing Islam Through a European Legal Prism in Light of the Sahin Judgment' (2006) 12 Columbia Journal of European Law 573, 583.

${ }^{21}$ [2006] UKHL 15, [94].

${ }^{22}$ Nusrat Choudhury, 'From the Stasi Commission to the European Court of Human Rights: L'Affaire du Foulard and the Challenge of Protecting the Rights of Muslim Girls' (2007) 16 Columbia Journal of Gender and Law 199, 218.
} 
belief conforms to or differs from the views of others professing the same religion. Freedom of religion protects the subjective belief of an individual ... religious belief is intensely personal and can easily vary from one individual to another. Each individual is at liberty to hold his own religious beliefs, however irrational or inconsistent they may seem to some, however surprising. ${ }^{23}$

I will now briefly consider the question of how bans or restrictions on religious dress have been answered in other jurisdictions. ${ }^{24}$ Given that these issues, as with many other legal issues, are of universal rather than territorial concern, and given that the issues have been explored by courts in other jurisdictions at some length, it is sensible to consider how other courts have approached these issues. The High Court of Australia and courts in other nations have increasingly been willing to consider legal developments in overseas jurisdictions in developing Australian jurisprudence. ${ }^{25}$ Recently the

${ }^{23} R v$ Secretary of State for Education and Employment; Ex parte Williamson [2005] 2 AC 246 [22] (Lord Nicholls); Employment Division, Department of Human Resources of Oregon $v$ Smith 494 US 872, 887 (1990); Syndicat Northcrest v Amselem (2004) 241 DLR $\left(4^{\text {th }}\right) 1,27$ [52]; Multani v Commission Scolaire Marguerite-Bourgeoys [2006] 1 SCR 256 [35]; Manoussakis v Greece (1997) 23 EHRR 387 [45]. Cf early cases, where the Court appeared judgmental of the religious views of others whose opinions the judges presumably did not share: Krygger v Williams (1912) 15 CLR 366, 370-2; Mormon Church v United States (1889) 136 US 1, 49.

${ }^{24}$ This raises a separate question as to the extent to which Australian law is, or should be, influenced by developments overseas. There is a rich jurisprudence on this question: see for example: Hilary Charlesworth et al, No Country is an Island: Australia and International Law (UNSW Press, 2006); Kristen Walker, 'International Law as a Tool of Constitutional Law Interpretation' (2002) 28 Monash University Law Review 85; Devika Hovell and George Williams, 'A Tale of Two Systems: The Use of International Law in Constitutional Interpretation in Australia and South Africa' (2005) 29 Melbourne University Law Review 95; Hilary Charlesworth, 'Dangerous Liaisons: Globalisation and Australian Public Law' (1998) 20 Adelaide Law Review 57.

${ }^{25}$ Justice Kirby was a consistent advocate of the importance of international law; see for example Newcrest Mining (WA) Ltd v Commonwealth (1997) 190 CLR 513, 657-8 ('international law is a legitimate and important influence on the development of the common law and constitutional law, especially when international law declares the existence of universal and fundamental rights. To the full extent that its text permits, Australia's Constitution, as the fundamental law of government in this country, accommodates itself to international law'), and in Kartinyeri v Commonwealth (1998) 195 CLR 337, 418: 'where there is ambiguity, there is a strong presumption that the Constitution ... is not intended to violate fundamental human rights and human dignity'; Al-Kateb v Godwin (2004) 219 CLR 562, 616-24; Michael Kirby 'Domestic Implementation of International Human Rights Norms' (1999) 5 Australian Journal of Human Rights 109. In the landmark Mabo decision, Brennan J concluded that 'international law is a legitimate and important influence on the development of the common law, especially when international law declares the existence of universal human rights': Mabo v Queensland (No 2) (1992) 175 CLR 1, 42. Some judges have been less enthusiastic: for example, Kartinyeri v Commonwealth (1998) 195 CLR 337, 384 (Gummow and Hayne JJ), AMS v AIF (1999) 199 CLR 160, 180 ('As to the Constitution, 
High Court has resorted more frequently to international materials, particularly in the rights context. For example, in Roach $v$ Electoral Commissioner $^{26}$ a High Court majority ${ }^{27}$ (over the express dissent by the minority $)^{28}$ expressly referred to international jurisprudence from Canada and Europe on the right to vote to justify its conclusion. In Betfair Pty Ltd $v$ Western Australia ${ }^{29}$ six members of the High Court made extensive reference to American jurisprudence in their consideration of section 92 of the Australian Constitution. The current and a former Chief Justice of the High

its provisions are not to be construed as subject to an implication said to be derived from international law': Gleeson CJ McHugh and Gummow JJ); Callinan J in Western Australia v Ward (2002) 191 ALR 1, 275 ('the provisions of the Constitution are not to be read in conformity with international law'); Al-Kateb v Godwin (2004) 219 CLR 562, 589 (McHugh J) ('courts cannot read the Constitution by reference to the provisions of international law that have become accepted since the Constitution was enacted in $1900 \ldots$ The claim that the Constitution should be read consistently with the rules of international law has been decisively rejected by members of this Court on several occasions. As a matter of constitutional doctrine, it must be regarded as heretical'; Roach v Electoral Commissioner (2007) 233 CLR 162, 221 (Hayne J) and 225 (Heydon J) (denying that international instruments such as the International Covenant on Civil and Political Rights or European Convention on Human Rights could (should) have any influence on interpretation of the Australian Constitution. Those who take this view often do so on the basis that the founding fathers could not have been influenced by these documents which post-dated the drafting of the Australian Constitution; however such a view reifies the intent of the founding fathers at the expense of a living organism view of the Constitution which has gained orthodoxy in the High Court. There is also evidence of British judges interpreting the common law consistent with, for example, the European Convention on Human Rights even prior to the enactment of the Human Rights Act: Attorney-General v Guardian Newspapers (No. 2) [1990] 1 AC 109, 283-4; $R v$ Advertising Standards Authority Ltd; ex parte Vernons Organisations Ltd [1993] 2 All ER 202; Derbyshire County Council v Times Newspapers [1992] QB 770, 811-12: see for discussion H Mountfield and M J Beloff, 'Unconventional Behaviour?: Judicial Uses of the European Convention in England and Wales' (1996) 5 European Human Rights Law Review 467; A Cunningham, 'The European Convention on Human Rights, Customary International Law and the Constitution' (1994) 43 International and Comparative Law Quarterly 537; R Higgins, 'The Relationship Between International and Regional Human Rights Norms and Domestic Law' (1992) 18 Commonwealth Law Bulletin 1268; New South Wales Chief Justice James Spigelman noted soon after the introduction of the Human Rights Act 1998 (UK) that the English common law was 'developing in the shadow of the jurisdiction of the European Court': 'Rule of Law: Human Rights Protection' (1999) 18 Australian Bar Review 29, 32. The United States Supreme Court has started to take into account international law in interpreting that country's Constitution: Atkins $v$ Virginia (2002) 536 US 304, 316; Lawrence $v$ Texas (2003) 539 US 558, 576-577; Grutter v Bollinger (2003) 539 US 306, 344 (Ginsburg J).

${ }^{26}$ (2007) 233 CLR 162.

${ }^{27}$ Gleeson CJ (177-9), Gummow Kirby and Crennan JJ (203-4).

${ }^{28}$ Hayne J (221) and Heydon J (225).

${ }^{29}$ (2008) 234 CLR 418, 459-64 (Gleeson CJ Gummow Kirby Hayne Crennan Kiefel JJ). 
Court have expressed support for the use of international materials in deciding Australian cases. ${ }^{30}$

\section{Bans on Religious DRESS in Other JURISDICTIONS}

\section{A Europe}

On first impressions, one might have thought that the protection given to religious freedoms by the European Convention on Human Rights might have meant that attempts to ban religious dress would founder. ${ }^{31}$ However, this has not in fact been the experience. Often, bans have been upheld as exercises of the 'margin of appreciation' allowed by the Convention to member states. ${ }^{32}$

Some cases have been brought under domestic 'racial discrimination' provisions, rather than 'right to religion' provisions. ${ }^{33}$ Section $45(3)$ of the

30 'It is...important that we do not allow legal insularity to hamper our national engagement with international legal systems. We should derive from these systems such benefits as they may offer to the development of our own law and our more effective interaction with other countries' (Chief Justice of Australia Robert French, 'Oil and Water? - International Law and Domestic Law in Australia' (The Brennan Lecture, Bond University, 26 June 2009), Former Chief Justice of Australia Murray Gleeson, 'Global Influences on the Australian Judiciary (Speech delivered at the Australian Bar Association Conference, Paris, 8 July 2002)); see also Chief Justice of New South Wales James Spigelman, 'Corporate Governance and International Business Law', (Book launch, 18 June 2009) and Justice Paul Finn, 'Internationalisation or Isolation: The Australian Cul de Sac? The Case of Contract Law' (Speech delivered at the Bond University $20^{\text {th }}$ Anniversary Symposium, 26-27 June 2009).

${ }^{31}$ Article 9 of the European Convention on Human Rights provides that everyone has the right to freedom of thought, conscience and religion, including the freedom to manifest one's religion or belief in worship, teaching, practice and observance. This right is subject only to such limitations as are prescribed by law and necessary in a democratic society in the interests of public safety, for the protection of public order, health or morals, or protection of the rights and freedoms of others.

${ }^{32}$ Dahlab v Switzerland (2001) European Court of Human Rights 1, on the basis that the teacher there was dealing with very young children such that their vulnerability to influence was high, and the court's conclusion that the wearing of the Islamic scarf there could not be reconciled with gender equality, tolerance, and non-discrimination; see also Leyla Sahin $v$ Turkey (Application No 44774/98), 10/11/2005.

${ }^{33}$ The Race Relations Act 1976 (UK) s 1 defines racial discrimination to include direct and indirect discrimination. Direct discrimination is discrimination against a person on racial grounds (race, nationality, ethnicity or national origins). Such discrimination is banned absolutely. Indirect discrimination is defined in s 1(1)(b) to mean applying a requirement or condition to those not of the same racial group (group defined by reference to colour, race, nationality, ethnic or national origin (s 3(1)) as the other, but where the proportion of those of the same racial group as the complainant who can comply with the requirement is considerably less than the proportion of those not of that racial group who can comply, where 
Equality Act 2006 (UK), is such a provision. It deals with indirect discrimination (to ' $\mathrm{B}$ ') so as to include applying a provision or practice

(a) ... equally to persons not of B's religion or belief; or putting

(b) ... persons of B's religion or belief at a disadvantage compared to some or all others (where there is no material difference in the relevant circumstances); or putting

(c) ... B at a disadvantage compared to some or all persons who are not of his religion or belief (where there is no material difference in the relevant circumstances),

in cases where

(d) ... the person committing the alleged discrimination cannot justify their actions by reference to matters other than the complainant's religion or belief. ${ }^{34}$

However such provisions are subject to exceptions. Article 9(2) of the European Convention on Human Rights provides that the right to freedom of religion is not absolute and is subject to limits provided by (domestic) law; however it requires that these limits be necessary in a democratic society in the interests of public safety, public order, health, morals and the rights of others. Extensive exceptions to racial discrimination laws appear in the Race

\footnotetext{
the discrimination is not justifiable irrespective of the colour, race, nationality or ethnic or national origins of the person to whom it is applied, and as a result the complainant suffers detriment. It includes cases where a person applies to the complainant a provision, criterion or practice applicable equally to those not of that race, ethnic or national origin, but which puts those of the race, ethnic or national origin of the complainant at a particular disadvantage compared with others, where it is not a proportional means of achieving a legitimate aim (s 1(1A)). These cases include (recently) The Queen on the Application of Watkins-Singh and the Governing Body of the Aberdare Girls' High School and Rhondda Cynon Taf Unitary Authority [2008] EWHC 1965 (Admin) and $R v$ Governing Body of JFS and the Admissions Appeal Panel of JFS [2009] UKSC 15.

${ }^{34}$ For example, in The Queen on the Application of Watkins-Singh and the Governing Body of the Aberdare Girls' High School and Rhondda Cynon Taf Unitary Authority [2008] EWHC 1965 (Admin) a school ban on wearing jewellery at school was overturned by the complainant, who wished to wear a Kara (plain steel bangle important to some Sikhs). The court found the policy to be indirectly discriminatory; it discarded comparisons with cases involving Islamic dress on the basis that those forms of dress were more visible, so arguments in that context about uniformity, coherence, and communal spirit were not relevant here. See also $R v$ Governing Body of JFS and the Admissions Appeal Panel of JFS [2009] UKSC 15, argued under the Race Relations Act 1976 (UK).
} 
Relations Act 1976 (UK) ${ }^{35}$, Equality Act 2006 (UK) and Equality Act 2010 (UK). Whether these extensive exceptions meet the 'margin of appreciation' allowed by the Convention in this area is a contentious matter. ${ }^{36}$ In the current context of a law banning the wearing of Islamic religious dress, Muslim people would clearly have a right to bring a complaint under the Equality Act 2006 (UK) and Equality Act 2010 (UK). It would be more difficult to bring a complaint under the Race Relations Act, given that its definition of discrimination relates to concepts such as 'race' and 'ethnic or national origin'. ${ }^{37}$ Given the standard definition of these concepts in Mandla, ${ }^{38}$ and the fact that Islam can be described as a 'heterogenous faith' without some of the elements of the Mandla definition, unless the definition were adapted it is questionable whether a follower of the Islamic faith could meet this threshold requirement. ${ }^{39}$

\section{B North America}

In its interpretation of the free exercise of religion and anti-establishment provisions of the First Amendment, the Supreme Court has moved from a requirement that a law affecting religious practice be justified by a

\footnotetext{
${ }^{35}$ Most importantly, s 4A and s 5 allow for exceptions to the non-discrimination requirements of the Act where it is justified by genuine occupational requirements (as does $\mathrm{cl} 7$ of the Employment Equality (Religion or Belief) Regulations 2003 (SI 2003/1660); see also s 19C, s 19D, s 19F, s 25 and ss 35-39 of the Act.

${ }^{36}$ Further, the concept of 'proportionality' appears in the Race Relations Act 1976 (UK) and Equality Act 2010 (UK) to allow some discrimination if it is a proportional means of achieving a legitimate end; this is not a feature of the European Convention. Nor does the Convention recognise the distinction between direct and indirect discrimination.

${ }^{37}$ Race Relations Act 1976 (UK) s 1(1)(b).

${ }^{38}$ Some have noted the slightly different meaning of the words in s $1(1 \mathrm{~A})$ of the Race Relations Act 1976 (UK) ('race or ethnic or national origins'), compared with the wording in s 1 (racial grounds, racial group), and acknowledged the provisions in s 1(1A) connote a broader concept than the Mandla definition of race to which reference is made later in the paper: $R v$ Governing Body of JHS [2009] UKSC 15, Lord Phillips [33], Lord Mance [94]. This difference may not be material in the context of discussing the Islamic faith.

39 The possibility exists, as Ann Blair notes, that a measure affecting Muslims could be challenged if it disproportionately affected people of Asian origin, given high Muslim populations in Indonesia and Malaysia: 'Case Commentary $-R(S B) v$ Headteacher and Governors of Denbigh High School - Human Rights and Religious Dress in Schools' (2005) 17(3) Child and Family Law Quarterly 7. Anne Hewitt agrees that a Muslim would in most cases not be able to meet the definition of 'race' or 'ethnic group': 'Muslims do not satisfy the test as a racial group because they are drawn from too diverse a range of backgrounds': 'It's Not Because You Wear Hijab, It's Because You're Muslim - Inconsistencies in South Australia's Discrimination Laws' (2007) 7(1) QUT Law and Justice Journal 57, 67.
} 
'compelling governmental interest ${ }^{40}$ to a more modest requirement that the law not be directed at specific religious practices, or ban the performance of acts solely because of their religious motivation. ${ }^{41}$ This more recent approach validates laws which incidentally affect a religious practice, but which are of general application and otherwise constitutionally valid. ${ }^{42}$ The United States Supreme Court considered a religious ban in Goldberg $v$ Weinberger, Secretary of Defense. ${ }^{43}$ At issue here was an air force regulation prohibiting employees from wearing headgear while indoors, as part of the uniform policy. An employee who was serving as a psychologist on an air force base was an Orthodox Jew and ordained rabbi, and wore a skullcap (yarmulke) while on duty indoors, and under his service cap whilst outdoors. He was informed by his commander that he was in breach of the air force uniform regulation and that, if he persisted, he could be the subject of a court martial. The employee claimed that the regulation was an infringement of his First Amendment right to free exercise of religion.

A majority of the Supreme Court upheld the regulation. The majority suggested that the court should be more deferential in the context of military provisions than in respect of provisions with civilian application. They stated that great deference should be given to the professional judgment of military authorities concerning the relative importance of a particular military interest. The military had a legitimate interest in ensuring 'instinctive obedience, unity,

${ }^{40}$ Sherbert $v$ Verner 374 US 398 (1963). In Wisconsin v Yoder 406 US 205 (1972) Chief Justice Burger wrote for the court that 'only those interests of the highest order and those not otherwise served can overbalance legitimate aims to the free exercise of religion' (215). The Court has not been impressed with laws that single out particular religions for special treatment: Church of Lukumi Babalu Aye v City of Hialeah 508 US 520 (1993).

${ }^{41}$ So, for instance, a law prohibiting public school teachers from wearing religious emblems or insignia in the workplace was invalid, because the law singled out clothing with religious connotations as opposed to jewellery or clothing more generally: Nichol $v$ Arin Intermediate Unit 28, 268 F. Supp 2d 536 (2003).

${ }^{42}$ Employment Division, Department of Human Resources of Oregon v Smith 494 US 872 (1990); see also the Religious Freedom Restoration Act 42 USC. 2000bb-1 (1993) in response to the Smith decision, and the Supreme Court's rejoinder in City of Boerne v Flores 521 US 507 (1997); Vincent Bonventre, 'Symposium: A Second-Class Constitutional Right? Free Exercise and the Current State of Religious Freedom in the United States' (2007) 70(4) Albany Law Review 1399; Steven K Green, 'Religious Liberty as a Positive and Negative Right' (2007) 70(4) Albany Law Review 1453. Pertinent to current argument is United States $v$ Lee 455 US 252 (1982), where the Court upheld a taxation law in the fact of an argument from a member of the Amish community that his beliefs precluded him from paying social security taxes. The Court concluded the community interest and benefit in an adequate system of social security overrode any legitimate objection on religious grounds.

${ }^{43} 475$ US 503 (1986). 
commitment and esprit de corps'. ${ }^{44}$ The regulation was not aimed at a particular religion. ${ }^{45}$ The dissentients, on the other hand, said the regulation set up an absolute bar to fulfilment of a religious duty. ${ }^{46}$ They dismissed the contention that the wearing of the skullcap would affect discipline within the forces as 'surpass(ing) belief'. ${ }^{47}$ It would not affect the government's military mission in the slightest.

Courts in the United States have upheld legislation prohibiting public school teachers from wearing religious clothing in class. ${ }^{48}$ Here courts have had to grapple with possible inconsistencies that could arise between the antiestablishment aspect of the First Amendment in relation to religion, and its free exercise. ${ }^{49}$ A decision to suspend a Sikh teacher for wearing white dress and a turban to school was upheld $;^{50}$ as was a decision to dismiss a Muslim teacher for wearing a headscarf in class. ${ }^{51}$ Some cases have been argued on the basis of alleged religious discrimination contrary to Title VII of the Civil Rights Act $1964 .{ }^{52}$ For instance, in Webb v City of Philadelphia, the United States District Court found the defendant was justified in insisting that the plaintiff not wear hijab to work; this was due to the need for uniformity, cohesiveness, co-operation and esprit de corps among police. Disallowing the

44 Ibid 507 (Burger CJ, White, Powell, Stevens and Rehnquist JJ; Brennan, Blackmun, O'Connor and Marshall JJ dissenting).

${ }^{45}$ Ibid 512.

${ }^{46}$ Ibid 513 (Brennan and Marshall JJ).

${ }^{47}$ Ibid 516 (Brennan and Marshall JJ).

48 This legislation exists in Oregon, Pennsylvania and Nebraska. Apparently these kinds of laws, now mostly repealed, were originally designed to prevent Catholic nuns and priests from teaching in public schools, reflecting anti-Catholic sentiment, although they were typically facially neutral in terms of religion: Stefanie Walterick, 'The Prohibition of Muslim Headscarves From French Public Schools and Controversies Surrounding the Hijab in the Western World' (2006) 20 Temple International and Comparative Law Journal 251, 264.

${ }^{49}$ Wojciech Sadurski, 'Neutrality of Law Towards Religion' (1990) 12 Sydney Law Review $420,427-47$.

${ }^{50}$ Cooper v Eugene School District 723 P 2d 298 (Or 1986).

${ }^{51}$ United States $v$ Board of Education for the School District of Philadelphia $911 \mathrm{~F} 2 \mathrm{~d} 882$, 893-4 (3d Cir, 1990); but see Nichol v Arin Intermediate Unit 28, 268 F Supp 2d 536 (WD Pa 2003), where an educational provider's dress code banning teachers from wearing Christian crosses or Stars of David was deemed to violate the free exercise clause). The United States Supreme Court has not yet decided whether the teacher dress statutes in these states is consistent with the First Amendment: see, for further discussion, Stefanie Walterick, 'The Prohibition of Muslim Headscarves From French Public Schools and Controversies Surrounding the Hijab in the Western World' (2006) 20 Temple International and Comparative Law Journal 251, 264-7.

5242 USC 2000e-16 (2007). 
hijab here ensured religious neutrality among police and avoided divisiveness. ${ }^{53}$

The most relevant Canadian precedent here is Multani v Commission Scolaire Marguerite-Bourgeoys. ${ }^{54} \mathrm{G}$ was a Sikh student in a Canadian school. He believed that his religion required him to wear a kirpan at all times. This is a religious object resembling a dagger and required to be made of metal. The school's governing board claimed that the wearing of the kirpan violated the school's code of conduct, which prohibited the carrying of weapons. It cited concerns with safety. It was suggested that $\mathrm{G}$ could wear a kirpan, as long as it was made of a non-metallic substance. $G$ refused this; he subsequently brought legal action alleging a breach of the freedom of religion provisions of the Canadian Charter of Rights and Freedoms. ${ }^{55}$

All members of the Supreme Court of Canada overturned a finding that the interference with religious freedom was justified by section 1 of the Charter. There was no doubt that the wearing of the kirpan had religious significance to $\mathrm{G}$, and that it was a genuinely held belief. G also believed that the wearing of a kirpan made of wood or plastic would not meet his religious obligations. The risk of G using his kirpan as a weapon was extremely low. While it could in theory be used as a weapon, it was above all a religious symbol; the word deriving from 'kirpa', meaning mercy, kindness and honour. Although the school's concern with safety was laudable, the school was required to provide a reasonable level of safety, not guarantee absolute safety. A ban on metallic kirpans was not a proportional response to the public interest in providing a safe environment in schools given the lack of any history of violence involving them, particularly when Canada had embraced multicultural values. ${ }^{56}$

\footnotetext{
${ }^{53}$ Webb v City of Philadelphia 2007 WL 1866763, 1 (E D Pa, June 27, 2007).

${ }^{54}$ [2006] 1 SCR 256.

${ }^{55}$ Canadian Charter of Rights and Freedoms s 2(a), as well as s 3 of the Quebec Charter of Human Rights and Freedoms. In both cases, as is the case with most human rights provisions, the rights expressed are not absolute - in the case of Canada, the allowance is for such 'reasonable limits as prescribed by law as can be demonstrably justified in a free and democratic society' (s 1 of the Charter). Examples where limits on religious freedom were justified include Ross v New Brunswick School District No 15 [1996] 1 SCR 825 and B (R) v Children's Aid Society of Metropolitan Toronto [1995] 1 SCR. 315; cf Amselem v Syndicat Northcrest [2004] 2 SCR 551.

${ }^{56}$ This value was also recognised in an Australian religious discrimination case: Catch the Fire Ministries Inc v Islamic Council of Victoria (2006) 15 VR 207, 241 (Nettle JA).
} 


\section{Summary}

Summarising the overseas jurisprudence, although human rights legislation in the nations surveyed provides, as does the Australian Constitution, for religious freedom, the freedom is not absolute. The courts have shown substantial deference to the decision of legislators that curbs on religious expression are necessary to further interests such as equality, assimilation, esprit de corps, women's rights and public safety. However, in some cases courts have upheld religious freedoms as against attempts by parliaments to take away such rights, particularly where the legislation or measure is seen as disproportionate to a legitimate objective, and where alternative means, less invasive of the right of religious liberty, are available to secure the legitimate objective. Some of these cases have been argued on the basis of discrimination principles, and key differences between the ECHR rights and rights under discrimination law have been noted. This is considered highly relevant to the position of Australia, to which our attention will now turn.

\section{The Australian Position}

As with the experience elsewhere, rights associated with religion are referred to both in the Constitution, and in discrimination legislation. ${ }^{57} \mathrm{I}$ will focus primarily on the constitutional provisions, given that my main question in this paper is the extent to which the Commonwealth could legislate to ban Islamic clothing. I will summarise the law first, before considering its application to a ban on religious dress.

\footnotetext{
${ }^{57}$ For example, in some states the legislation makes discrimination based on religion or religious belief unlawful: Anti-Discrimination Act 1991 (Qld) s 7(i); Anti-Discrimination Act 1998 (Tas) s 16(o); Equal Opportunity Act 2010 (Vic) s 6(n); Equal Opportunity Act 1984 (WA) pt IV; Discrimination Act 1991 (ACT) s 7(i); Anti-Discrimination Act 1992 (NT) s $19(1)(\mathrm{m})$. Of indirect relevance are provisions outlawing discrimination on the basis of race: Racial Discrimination Act 1975 (Cth) s 9; Anti-Discrimination Act 1977 (NSW) pt 2; AntiDiscrimination Act 1991 (Qld) s 7(g); Equal Opportunity Act 1984 (SA) pt 4; AntiDiscrimination Act 1998 (Tas) s 16(a), Equal Opportunity Act 2010 (Vic) s 6(m); Equal Opportunity Act 1984 (WA) pt III; Discrimination Act 1991 (ACT) s 7(h); AntiDiscrimination Act 1992 (NT) s 19(1)(a). See for further discussion of these statutes Garth Blake, 'God, Caesar and Human Rights: Freedom of Religion in Australia in the $21^{\text {st }}$ Century' (2009) 31 Australian Bar Review 279; Reid Mortensen, 'Rendering to God and Caesar: Religion in Australian Discrimination Law' (1995) 18 University of Queensland Law Journal 208; religious vilification is also proscribed in some jurisdictions: Patrick Parkinson, 'Religious Vilification, Anti-Discrimination Laws and Religious Minorities in Australia: The Freedom to be Different' (2007) 81(12) Australian Law Journal 954.
} 
The Racial Discrimination Act 1975 (Cth) applies to the Commonwealth. ${ }^{58}$ Section 9 prima facie prohibits distinctions based on race, colour, descent or national or ethnic origin which impair the exercise of human rights and section 10 provides for equality before the law, denying the validity of laws which mean that a person of a particular race, nationality or ethnic origin does not enjoy rights enjoyed by others of another race. However, there is debate as to the extent to which these provisions could apply to discrimination based on religion, rather than on race, and the Commonwealth could always amend the provisions of the Act since there is nothing enshrining its contents.

When we consider the validity of a state law banning religious dress, the question of discrimination becomes more important. This is because, while the Commonwealth may well be able to pass discriminatory legislation provided that a head of power exists, the states would find it more difficult, given possible inconsistency between such legislation and the Racial Discrimination Act 1975 (Cth). Obviously, if there were inconsistency between a state Act and the Racial Discrimination Act 1975 (Cth), the state act would, by virtue of section 109 of the Constitution, be invalid. The same fate could not befall Commonwealth legislation.

Constitutionally, section 116 prohibits the Commonwealth from passing any law establishing a religion or from prohibiting the free exercise of any religion. ${ }^{59}$ Very few cases alleging a breach of section 116 have been brought, and in no case has a law been struck down as being offensive to section 116 . The leading case is Adelaide Company of Jehovah's Witnesses Incorporated $v$ Commonwealth. ${ }^{60}$ There the federal government seized property owned by the plaintiffs pursuant to powers conferred on the Governor-General by national security regulations. The plaintiffs had been declared by that individual to be prejudicial to the war effort. It was said that followers of the Jehovah's Witness faith believed the Australian Government to be organs of Satan; they declined to take an oath of allegiance to the monarch, and believed that God's law prevailed over Parliament's laws. The Adelaide Company argued that the regulations were not supported by the defence power, and that they were inconsistent with section 116, in particular the free exercise of religion aspect.

\footnotetext{
${ }^{58}$ Racial Discrimination Act 1975 (Cth) s 6.

${ }^{59}$ The section also prevents the Commonwealth from passing a law imposing any religious observance, or imposing a religious test as a qualification for office or public trust under the Commonwealth, but these aspects of s 116 have never been litigated. Some tension between clauses in s 116 are possible, in particular the anti-establishment and free exercise aspects: Wojciech Sadurski, 'Neutrality of Law Towards Religion' (1990) 12 Sydney Law Review 420, 427; Joshua Puls, 'The Wall of Separation: Section 116, the First Amendment and Constitutional Religious Guarantees' (1998) 26(1) Federal Law Review 139, 159-60.

${ }^{60}$ (1943) 67 CLR 116.
} 
The Court decided the matter on the defence power argument and invalidated the law; the judges considered (in dicta) the reach of section 116. Latham CJ noted that section 116 protected the 'exercise' of religion; this included acts done in pursuance of religious beliefs as part of religion. ${ }^{61} \mathrm{He}$ noted the strong similarity between section 116 and the relevant provisions of the United States Constitution, to which reference was made above, concluding that there was 'full legal justification for adopting in Australia an interpretation of section 116 which had, before the enactment of the Commonwealth Constitution, already been given to similar words in the United States' ${ }^{62} \mathrm{He}$ concluded, in terms with which the others agreed, ${ }^{63}$ that the religious freedom protected by section 116 was not absolute, and would be subject, at least, to the validity of laws passed designed to ensure the maintenance of civil government. ${ }^{64} \mathrm{He}$ inferred that a balancing exercise was necessary in relation

${ }^{61}$ Ibid 124.

${ }^{62}$ Ibid 131; Starke J also observed that the Australian provision was substantially the same as the United States provision, and referred to the American case law (155); speaking of the similarity, Pannam spoke of the 'fairly blatant piece of transcription' involved in the drafting of s 116: Clifford L Pannam, 'Travelling Section 116 with a US Road Map' (1963) 4 Melbourne University Law Review 41, 41. On the other hand, in at least two respects the interpretation of the two provisions has diverged: in relation to government funding for certain denominational schools, this was invalidated as a breach of the First Amendment antiestablishment clause in Everson v Board of Education 330 US 1, 15 (1947) (although see now Zelman v Simmons-Harris 536 US 639 (2002)) but upheld by the High Court of Australia despite a s 116 challenge in Attorney-General (Vic) ex rel Black v Commonwealth (1981) 146 CLR 559; further the United States Supreme Court has interpreted the anti-establishment clause broadly to invalidate laws which advance or benefit religion (see, eg, McCreary County v ACLU of Kentucky 545 US 844 (2005)) while the High Court of Australia has interpreted it strictly to forbid only the actual establishment of a religion (Attorney-General (Vic) ex rel Black v Commonwealth (1981) 146 CLR 559); see for further discussion Wojciech Sadurski, 'Neutrality of Law Towards Religion' (1990) 12 Sydney Law Review 420. The question of the extent to which the American provision was similar to, and thus should guide interpretation of, the Australian provision divided the High Court of Australia in Attorney-General (Vic) ex rel Black v Commonwealth (1981) 146 CLR 559, with a majority emphasising the literal differences (laws 'for' in s 116, compared with laws 'respecting' in the First Amendment: Barwick CJ 579, Gibbs J 598, Wilson J 653; Cf Murphy J 622 (dissenting).

${ }^{63}$ Adelaide Company of Jehovah's Witnesses Incorporated $v$ Commonwealth (1943) 67 CLR 116, 149 (Rich J).

${ }^{64}$ Ibid 126; similarly Rich J (149) and Starke J (155), who referred to laws 'reasonably necessary for the protection of the community and in the interests of social order' being valid, despite interference with religious freedoms; McTiernan $\mathrm{J}$ referred to laws so the 'Commonwealth could defend itself against invasion' (157); and Williams J spoke of laws necessary to ensure the nation was safe and its existence preserved (160). Although these comments were made in dicta, they are narrower than the margin of appreciation exception that the European Court has applied in its decisions in relation to laws that restrict religious freedoms, but which arguably do so for justified reasons. It may be that if the High Court were again asked to consider a law in terms of s 116, it would cast the 'margin of appreciation' more broadly than the dicta comments in Jehovah's Witness suggest. 
to laws challenged under the provision, where the end sought to be achieved by the law which was invasive of religious freedom would be weighed against the extent to which religious freedom had been infringed. This would establish whether the infringement was 'undue'. ${ }^{65}$

Another leading case on section 116 was Attorney-General for the State of Victoria (ex rel Black) v Commonwealth of Australia, ${ }^{66}$ involving a challenge to Commonwealth financial support to non-government schools. The Court concluded that financial support to such schools did not infringe the antiestablishment aspect of section 116. Most relevant here is the discussion by the judges of whether laws caught by section 116 needed to have a particular purpose. A clear majority of the judges thought that the section was directed to prohibiting laws that had a particular purpose, such as (in the context of that case) the purpose of establishing a religion, ${ }^{67}$ although two of this majority seemed to allow the possibility that the provision could catch laws with this effect - Gibbs $\mathrm{J}^{68}$ and Mason $\mathrm{J}^{69}$ When these judgments are considered together with those of Stephen and Murphy JJ, this can be taken to be a majority in Black in favour of section 116 applying to laws which affected religion, although that effect was not the purpose, or main purpose, of the legislation. ${ }^{70}$

This debate continued in Kruger $v$ Commonwealth ${ }^{71}$ There the court concluded that, in order for a law to be offensive to the section, it must have THE

\footnotetext{
${ }^{65}$ Ibid 128.

${ }^{66}$ (1981) 146 CLR 559.

${ }^{67}$ Ibid 584 (Barwick CJ), 598 (Gibbs J), 615 (Mason J), 653 (Wilson J); in contrast Stephen J said that the anti-establishment clause of s 116 (at least) was directed to laws with a particular effect (605), Murphy J said it meant 'with respect to' or concerning religion (622).

${ }^{68}$ Ibid 604: 'purpose or effect'.

${ }^{69}$ Ibid 615: 'purpose or result'.

${ }^{70}$ Reference to the effect of the legislation, as opposed to its purpose, in the context of s 116 also appears in lower court decisions. See, eg, Sundberg J in Halliday $v$ Commonwealth of Australia [2000] FCA 950 [21]: 'Nor is it a law that has the result or effect of prohibiting the free exercise of a Muslim's or anyone else's religion'. In Minister for Immigration and Ethnic Affairs v Lebanese Moslem Association (1987) 17 FCR 373, two members of the Court alluded to this matter, with Fox J applying the test of whether the law had the 'purpose or effect' of establishing a religion, prohibiting the free exercise etc (374). In other words, a law with either the purpose or the effect of infringing religious freedoms could, according to the court, be offensive to s 116. This is clearly broader than the view in Kruger (discussed below). Jackson $\mathrm{J}$ assumed that the purpose of the law could be gathered from its effect or result, such that if the law had the effect proscribed by s 116, it would be deemed to have had this purpose (388).

${ }^{71}$ (1997) 190 CLR 1.
} 
purpose of achieving an object which section 116 forbids. ${ }^{72}$ Presumably, a law without this purpose, but having this effect, would not be offensive to section 116 , according to this view. ${ }^{73}$ This view, which is presumably ${ }^{74}$ based on the word 'for' in the section, ${ }^{75}$ has the effect of limiting the impact of the section and its ability to protect religious freedoms. ${ }^{76}$

Given the relative dearth of authority concerning section 116 in Australia, fundamental issues such as the purpose of the section have remained relatively unresolved. In the light of past experiences, particularly in other jurisdictions, where some governments acted to impose particular religious views and/or suppress minority religious views, it is possible to read the

${ }^{72}$ To like effect are comments of Mason ACJ and Brennan J in Church of the New Faith $v$ Commissioner of Payroll Tax (Vic) (1983) 154 CLR 120, 135-6 that laws which do not discriminate against religion generally or against particular religions or against conduct of a kind which is characteristic only of a religion are not offensive to s 116.

${ }^{73}$ Gaudron J claimed in Kruger $v$ Commonwealth (1997) 190 CLR 1 that purpose was the 'criterion and sole criterion' selected by s 116 for invalidity (132). Toohey J was slightly more equivocal in that case, concluding that the purpose should be taken into account, and referring to whether it was necessary that ' $a$ purpose' be to prohibit the free exercise of religion, rather than this being the predominant or only purpose, for the provision to be invalid under s 116 (86). See also Latham CJ in Adelaide Company of Jehovah's Witnesses Inc v Commonwealth (1943) 67 CLR 116 who argued that purpose was a factor to be taken into account (132). See also comments considering the 'effect' of legislation in relation to $\mathrm{s} 116$ in Minister for Immigration and Ethnic Affairs $v$ Lebanese Moslem Association (1987) 17 FCR 373, 374 (Fox J) and 388 (Jackson J), and Halliday v Commonwealth of Australia [2000] FCA 950 [21] (Sundberg J). For criticism of the High Court's approach here see Stephen McLeish, 'Making Sense of Religion and the Constitution: A Fresh Start for Section 116' (1992) 18 Monash University Law Review 207, 233.

${ }^{74}$ No reason is given by Brennan CJ in Kruger v Commonwealth (1997) 190 CLR 1; the assertion that, 'to attract invalidity under s 116, a law must have the purpose of achieving an object which s 116 forbids' appears without reference to prior authority or further elaboration of rationale.

${ }^{75}$ Toohey J justified it on this basis in Kruger (86), citing the judgment of Barwick CJ in Attorney-General (Vic) ex rel Black v Commonwealth (1981) 146 CLR 559 for the proposition, as did Gaudron J (132-3); Gummow J took the same view, citing the judgment of Gibbs $\mathrm{J}$ in Black (160). It was not necessary for Dawson and McHugh JJ to consider this issue, because of their view that s 116 did not apply to laws passed pursuant to s 122 . However, the view that the word 'for' means that the law has a particular purpose has been challenged, with Dixon J in Lamshed $v$ Lake (1958) 99 CLR 132, 141 concluding that 'for' (in the context of s 122) meant 'with respect to'; see also Murphy J in Black, 622.

${ }^{76}$ There are links here with the American jurisprudence, most notably Employment Division, Department of Human Resources of Oregon v Smith 494 US 872 (1990), where the United States Supreme Court moved from a requirement that a law affecting religious practice be justified by a compelling governmental interest to a more modest requirement that the law not be directed at specific religious practices, validating laws that may incidentally affect religious freedoms in pursuance of another objective. 
section as a strong assertion (re-assertion) of the separation of church from state. Murphy $\mathrm{J}$ (dissenting) alluded to this history briefly in Black. ${ }^{77}$

An example of this view is contained in a letter from Thomas Jefferson to a group of Danbury Baptists:

Believing with you that religion is a matter which lies solely between man and his God; that he owes account to none other for his faith or his worship; that the legislative powers of government reach actions only, and not opinions - I contemplate with sovereign reverence that act of the whole American people which declared that their legislature should 'make no law respecting an establishment of religion or prohibiting the free exercise thereof', thus building a wall of separation between church and state. Adhering to this expression of the supreme will of the nation in behalf of the rights of conscience, I shall see with sincere satisfaction the progress of those sentiments which tend to restore man to all his natural rights, convinced he has no natural right in opposition to his social duties. ${ }^{78}$

The section might, on the other hand, be read more modestly, as simply a clarification by the drafters of the Constitution that matters of religion or

\footnotetext{
77 'The purpose of the United States establishment clause was clearly to prevent the recognition of and assistance to religion which plagued European countries over many centuries. The religious wars of ancient times were repeated after the Middle Ages and into modern times. In the United Kingdom the struggle between the contending Catholic and Protestant factions, with the emergence of Presbyterians, Methodists, Quakers, Lollards and many other religious groups, was a bitter illustration of the attempts of religious factions to get the assistance of the state in propagating their views and if possible suppressing their rivals': (1981) 146 CLR 559, 625. The colonies that would unite to become Australia did not experience this kind of angst based on religious differences and there was not the experience of a government-imposed religion or (formal) sanctions against minority religions, although Stephen J in AttorneyGeneral (Vic) ex rel Black v Commonwealth (1981) 146 CLR 559 comments that the creation of a state church nearly occurred in the years prior to federation (608). Mason $\mathrm{J}$ in the same case states that s 116 reflected the 'expression of a profound sentiment favouring religious equality in the Australian colonies' (615). Pannam notes that there has been little evidence of official religious intolerance or discrimination in Australia, and that s 116 differs from its American counterpart in that it does not reflect a long struggle for religious freedom: Clifford L Pannam 'Travelling Section 116 with a US Road Map' (1963) 4 Melbourne University Law Review 41, 50.

${ }^{78}$ This passage was referred to with approval in the United States Supreme Court decision Everson v Board of Education (1947) 330 US 1. See also Chief Justice Burger in Walz v Tax Commission of the City of New York (1970) 397 US 664, 669: 'we will not tolerate either governmentally established religion or governmental interference with religion'. In Church of the New Faith v Commissioner of Payroll Tax (Vic) (1983) 154 CLR 120, 130 Mason ACJ and Brennan J claimed that 'freedom of religion, the paradigm freedom of conscience, is of the essence of a free society'.
} 
religious observance were intended to be matters regulated by state governments rather than by the then new federal government. ${ }^{79}$

\section{A Would a Commonwealth or State Law With the Effect of Banning the Hijab or Burqa Be Constitutionally Valid?}

\section{Commonwealth Law}

Assuming that the Commonwealth did attempt to legislate a ban on religious dress including the hijab or burqa, at least in some contexts, would a constitutional challenge be successful $?^{80}$ For discussion purposes, it may be best to be specific. Assume that a law is passed making it an offence for a person to appear in public whilst their face is covered. Whilst the law is facially neutral, it is clear (for example, from the Minister's speech and the events preceding the introduction of the law) that it is intended to be applied specifically to stop women of the Islamic faith from wearing a burqa or hijab in public, though it may have other applications as well. While section 116 deals with a number of different types of law, I will confine the discussion to that limb of the section preventing the Commonwealth from passing a law prohibiting the free exercise of religion, since that is the limb of prime relevance to the discussion. ${ }^{81}$

\footnotetext{
${ }^{79}$ This was apparently the view of at least Higgins in the Convention Debates: 'the powers that the states individually have of making such laws as they like with regard to religion shall remain undisturbed and unbroken, and to make it clear that in framing this Constitution, there is no intention whatever to give to the Federal Parliament the power to interfere in these matters ... I simply want to leave things as they are. I do not want to interfere with any right the state has': Official Record of the Debates of the Australasian Federal Convention (Third Session), Melbourne, 20 January - 17 March 1898, 1769. However, originally the section applied to state laws, and the section appears in a part of the Constitution entitled 'The States'. See also Attorney-General (Vic) ex rel Blackv Commonwealth (1981) 146 CLR 559, 609: '(s 116) cannot readily be viewed as the repository of some broad statement of principle concerning the separation of church and state, from which may be distilled the detailed consequences of such separation...by fixing upon four specific restrictions of legislative power, the form of the section gives no encouragement to the undertaking of any such distillation' (Stephen J), and Kruger v Commonwealth (1997) 190 CLR 1, 125: '(s 116) must be construed as no more than a limitation on Commonwealth legislative power' (Gaudron J).

${ }^{80}$ I assume for current purposes that a head of power exists. I do not propose to discuss the possible heads of power to support such legislation in any depth; however ss 51(29) and (6) are possible sources. More detailed consideration of this issue is beyond the scope of the article, which is focused on the constitutionality of a ban in terms of s 116 .

${ }^{81}$ Such a law would clearly not establish a religion, and it would not impose a religious observance, or impose a religious test as a requirement of Commonwealth office.
} 
It is argued that such a law would prohibit the 'free exercise of religion', and so prima facie be invalid pursuant to section 116. While there are different views of the meaning of wearing particular clothing such as the burqa, at least some link between its wearing and religion has been established. A law banning its wearing would appear prima facie to be a prohibition of the free exercise of religion.

There have been few cases on the section to assist with interpretation. As with its rights jurisprudence more generally, the High Court has tended to read express provisions in the Constitution conferring religious freedoms conservatively. In Kruger, Black and Church of the New Faith, members of the Court claimed that in order to be invalid under section 116, the law would have to have THE purpose of prohibiting the free exercise of religion. If this narrow interpretation were continued, the Commonwealth might argue the purpose of the law is quite benign - as has happened in the cases cited earlier, for instance, that the law promotes civil 'unity' or prevents the subjugation of women that some argue is symbolised by the burqa, as has occurred in the European ${ }^{82}$ and American cases. ${ }^{83}$ Given the law does not expressly apply to such clothing, it could also be justified on public safety grounds - that individuals in society need to be identifiable. If this argument were accepted, the law may be valid; its purpose might be held to be legitimate; while there would be an effect on religious expression, it may not be sufficient, according to Kruger and Black, to invalidate the law, because the law lacked such a purpose ${ }^{84}$ In the language of Mason ACJ and Brennan J in Church of the New Faith, the law would not discriminate against religion, or against conduct which was characteristic only of a religion. ${ }^{85}$

It is generally contended that human rights are not absolute, and the courts often engage in a balancing exercise, comparing the infringement of human rights the legislation might create with legitimate objectives to which it might be aimed. Latham CJ made this comment expressly in relation to religious

\footnotetext{
${ }^{82}$ See, eg, Dahlab v Switzerland (2001) European Court of Human Rights 1; Leyla Sahin v Turkey (Application No 44774/98), 10/11/2005.

${ }^{83}$ See, eg, Employment Division, Department of Human Resources of Oregon et al v Smith 494 US 872 (1990); Goldberg v Weinberger, Secretary of Defense 475 US 503 (1986).

${ }^{84}$ This narrow view of the $\mathrm{s} 116$ protection was also taken by Mason ACJ and Brennan $\mathrm{J}$ in Church of the New Faith $v$ Commissioner of Payroll Tax (Vic) (1983) 154 CLR 120, 135-6 where his Honour concluded that conduct was not protected by s 116 if it did "not discriminate against religion generally or against particular religions or against conduct of a kind which is characteristic only of a religion'. Similar comments are made by Griffith CJ in Krygger $v$ Williams (1912) 15 CLR 366, 369: 'to require a man to do a thing which has nothing at all to do with religion is not prohibiting him from a free exercise of religion'.

${ }^{85}$ Church of the New Faith $v$ Commissioner of Payroll Tax (Vic) (1983) 154 CLR 120, 135-6.
} 
freedom in the Jehovah's Witness case. There the court said that religious freedoms would have to cede to laws deemed necessary to preserve the maintenance of a civil government. The cases referred to above from Europe and North America also reflect a balancing exercise, considering the supposed need for laws that might incidentally affect human rights, their proportionality to any claimed legitimate ends, the availability of less invasive measures to achieve the legitimate objective etc.

Considering the Australian precedents, a law prohibiting a person from appearing in public whilst their face was covered would be difficult to justify on the grounds discussed in the Jehovah's Witness case. It is difficult see how such a ban would be necessary to 'preserve a civil government'. When the matter is considered again, the High Court may adopt different words in expressing a test for when laws which infringe religious freedom may nevertheless be valid.

Despite this, on the current state of the High Court jurisprudence on section 116 , a law with the effect of banning religious dress such as a burqa would probably not be unconstitutional. This is because it would not meet the current test for invalidity set out in Kruger and Black ie that only a law with the express purpose of infringing the rights mentioned in section 116 is invalidated by that section. The federal government could state that its purpose in enacting the law was to promote civil harmony or assimilation, or to promote public safety by making it easier to identify everyone, and according to the High Court, this would be a decisive factor in declaring the law to be valid. The court might draw on the European and American precedents in support of this position, to find that the law was justified in terms of preserving equality and liberty among citizens, and avoiding supposed subjugation of women. However, as has been indicated, the research is difficult to reconcile with a bald assertion that the wearing of religious dress such as the burqa is necessarily a sign of subjugation of women or gender or religious inequality.

I would prefer the High Court took a broader view to the question of the rights protected by section 116 of the Constitution than previous cases have provided. The test in Kruger for invalidity pursuant to the section, that the law be passed with the purpose of restricting religious freedom, is with respect too narrow. As interpreted by the High Court, this section has very little operation, in that the Commonwealth, by carefully drafting its legislation, can ensure that its law avoids invalidity under section 116, even when the law clearly has the effect of restricting the rights implied in section 116 . There is hope for a broader view, with some of the judgments in Black allowing that a law which had the effect or result of interfering with religion may be 
offensive to section 116 , even if that were not its purpose. ${ }^{86}$ This is of course not the only context in which the High Court has read 'rights' contained in the Constitution narrowly, so that they have little if any scope and can be subverted by intelligent drafting. ${ }^{87}$ Rights provisions must not be read pedantically or narrowly, or in such a way as to make them easy for the drafter to subvert. Nor should the courts blindly accept claims by parliament that limits on religious freedoms are justified on 'equality', 'assimilation', 'esprit de corps' or 'women's rights' grounds as has occurred elsewhere, without a thorough investigation of the evidence.

This issue divided the United Kingdom Supreme Court recently in $R v$ Governing Body of JFS. ${ }^{88}$ There, in the context of considering a complaint under the Race Relations Act 1976 (UK)(rather than religious freedom per se), several judges indicated either unreservedly, ${ }^{89}$ or with some reservations, ${ }^{90}$ that the motive of the decision maker was not relevant in considering whether their behaviour constituted discrimination under that legislation. Further, as Lord Mance indicated in that case, the International Convention on Elimination on all Kinds of Racial Discrimination prohibits discrimination on the ground of race/national or ethnic origin if it has the purpose or effect of impairing the exercise of human rights. Whilst it is appreciated that this provision is not automatically relevant in the context of discussing protection of a right in a Constitution (or Convention) rather than discrimination legislation, there seems to be little logic in applying different principles in the discrimination context than to discrimination in the context of a constitutional freedom, where the text does not require it. Anti-discrimination rights are remedial in nature, and no pedantic or narrow view should be taken of them.

\footnotetext{
${ }^{86}$ As earlier noted, Gibbs, Stephen, Mason and Murphy JJ.

${ }^{87}$ Section 80 is one example: Amelia Simpson and Mary Wood, 'A Puny Thing Indeed Cheng $v$ The Queen and the Constitutional Right to Trial by Jury' (2001) 29 Federal Law Review 95; James Stellios, 'The Constitutional Jury - A Bulwark of Liberty?' (2005) 27 Sydney Law Review 113; James Stellios, 'The High Court's Recent Encounters with Section 80 Jury Trials' (2005) 29 Criminal Law Journal 139; Anthony Gray, 'Mockery and the Right to Trial by Jury' (2006) 6(1) QUT Law and Justice Journal 66.

${ }^{88}$ [2009] UKSC 15.

${ }^{89}$ Lord Phillips [20], Lady Hale [57], and Lord Mance [81].

${ }^{90}$ Lord Kerr concluded that a benign motive would not save otherwise discriminatory behaviour, but that mental processes leading to the decision may be considered [120]; Lord Clarke found that state of mind was irrelevant [132] but conceded that sometimes at a preliminary stage questions of motive might be relevant [145], as did Lord Walker [192]
} 
The approach of the Canadian court in Multani is also preferred here, asking whether the religious ban is proportional ${ }^{91}$ to a legitimate objective, and taking into account the multicultural nature of modern society, as well as values of tolerance. In the author's view, such an approach would better balance the right to religious freedom with other fundamental rights in society, and ensure that the section would have some substantive effect, rather than the intent of the section being easily subverted, which the current interpretation allows. Such an approach would not be foreign to Australia; it would be similar in approach to the High Court's interpretation of the implied freedom of political communication, which also reflects an approach balancing fundamental human rights with legitimate reasons that parliament may have for curtailing such rights in some cases. ${ }^{92}$ It is what Latham CJ was surely suggesting in Adelaide Company when he reiterated that the section 116 freedom was not absolute, and that it was a matter for the Court to determine whether the interference with religion created by a law was an 'undue' one. ${ }^{93}$

Adoption of this position would allow the accommodation of cases where laws with legitimate aims, and with incidental and marginal impact (if any) on religion, are not invalidated by virtue of section 116. So, for example, facts evident in cases such as Daniels $v$ Deputy Commissioner of Taxation, ${ }^{94}$ involving a challenge to taxation laws on the basis that a very small percentage of moneys so raised were spent on procedures of which the applicant strongly disagreed. A challenge to tax law on such grounds should fail because the effect of the tax law on religious views, if any, is so slight and incidental as not to amount to an infringement of section 116 rights, which are not absolute.

\footnotetext{
${ }^{91}$ This concept is also embraced in the context of United Kingdom discrimination legislation: Race Relations Act 1976 s 1, Equality Act 2010 s 19, and Equality Act 2006 s 45. This would allow the Commonwealth to enact laws which truly had marginal and incidental impact on religion, such as taxation laws (Halliday v Commonwealth [2000] FCA 950) and border control (Minister for Immigration and Ethnic Affairs $v$ Lebanese Moslem Association) (1987) 71 ALR 578).

92 Coleman v Power (2004) 220 CLR 1.

${ }^{93}$ Adelaide Company of Jehovah's Witnesses Incorporated v Commonwealth (1943) 67 CLR $116,131$.

${ }^{94}$ Daniels v Deputy Commissioner of Taxation [2007] SASC 431 (where a very small amount of taxation raised was paid in Medicare rebates for abortion services, about which the applicant complained on the basis of s 116). His arguments were, correctly in the author's view, rejected.
} 
Similarly, such an approach would support the decision reached in Halliday $v$ Commonwealth of Australia, ${ }^{95}$ where a member of the Muslim community objected to the goods and services tax because the system may, depending on whether persons with whom the business dealt had an $\mathrm{ABN}$ or not, require the applicant to collect taxation revenue on behalf of the government. The applicant claimed this was offensive to his Muslim beliefs, including specifically the obligation not to 'tax, tithe or charge interest'. Sundberg J in that case dismissed the section 116 objection on the basis that the government's interest in a sound and broad based tax system was of such a high order that it overrode any conflicting religious belief, ${ }^{96}$ again reflecting a balancing/proportionality approach espoused by the Canadian court in Multani and by Latham $\mathrm{CJ}$ in Adelaide Company. ${ }^{97}$

Another argument regarding the possible application of section 116 here might be that such a law does not 'prohibit' the free exercise of religion; rather, it limits one possible manifestation of that religion, namely the wearing of a face veil. The word 'prohibit' is obviously a strong one - it certainly would prevent laws banning particular religions, but arguably a ban on the wearing of a face veil does not 'prohibit' the free exercise of Islam (of course, to the extent that the wearing of the veil is a free exercise of Islamic beliefs). It merely limits one aspect of it. ${ }^{98}$ The woman would be free to wear the veil in the home, and practice other manifestations of that faith.

\footnotetext{
95 [2000] FCA 950.

${ }^{96}$ Ibid [21]. Sundberg J was fortified in this view by the fact that the applicant could, by carefully choosing those with whom he dealt business wise, avoid having to collect the tax on the government's behalf. His Honour also used the 'purpose' test in considering whether the law infringed s 116, though I have suggested earlier in this paper that this test should not be used.

${ }^{97}$ Adelaide Company of Jehovah's Witnesses Incorporated v Commonwealth (1943) 67 CLR 116. On similar facts, it will be recalled that the United States Supreme Court took a similar approach in United States $v$ Lee in rejecting a challenge to social security taxation laws by a person of the Amish faith. The Court found that the public interest in a robust, broad-based social security taxation system overrode individual objections on religious grounds, even if genuinely held: 455 US 252 (1982).

${ }^{98}$ There have been suggestions that s 116 does not prevent the Commonwealth from passing a law which would have the effect of making a particular aspect of a religious activity contrary to law: Church of the New Faith v Commissioner for Payroll Tax (Vic) (1983) 154 CLR 120, 135-6 (Mason ACJ and Brennan J); $R v$ Gorton [2001] QCA 43. Similar in some ways is the reasoning of Barton J in Krygger $v$ Williams (1912) 15 CLR 366, 372 dismissing the applicant's religious objections to having to obtain military training on the basis that the applicant could still exercise his religion freely if he did the required training. Similarly here, it could be argued that this ban does not stop anyone from exercising their religious faith in other ways, as long as they respect the public ban on face covering. Applying these principles, Sundberg J in Halliday v Commonwealth of Australia [2000] FCA 950 states that the goods
} 
On the other hand, there is evidence that most, if not all, Muslim women would not wear the veil in private anyway, because the whole point of it is to subvert the gaze of men who are strangers to the woman, and these interactions are overwhelmingly going to occur in public.

Such a ban may well infringe the Racial Discrimination Act 1975 (Cth), about which more will be said below in the context of a state ban on the burqa. However, it is of course open to the federal parliament to amend or repeal the Racial Discrimination Act 1975 (Cth) as they see fit.

\section{$2 \quad$ State Law}

The religious freedom contained in section 116 is expressly confined to laws passed by the Commonwealth. As a result, it would be difficult to argue against the law on the basis of that section. ${ }^{99}$

An argument may be made against such state laws by having regard to discrimination laws. Here the focus will be on federal discrimination laws. Although each state has its own discrimination laws, these could easily be amended or repealed. A later law inconsistent with an earlier law is implicitly deemed to amend or repeal the earlier law, even in the absence of express words. Further, each state parliament has generally plenary law making powers ${ }^{100}$ to pass laws for the peace, welfare and good government of the State.

A stronger argument would be that the state law was inconsistent with the Racial Discrimination Act 1975 (Cth), and invalid for that reason. ${ }^{101}$ Section

and services tax law considered there 'at most ... requires a person to do an act that his religion forbids. But that is not within s 116' [21].

${ }^{99}$ Elsewhere, I have made an argument that express constitutional rights, including the right to freedom of religion, should (despite the express words of the Constitution) apply to the states: Anthony Gray, 'Applying Provisions of the Constitutions to Protect Human Rights from Intrusion by State Governments' (2011) 18(4) Australian Journal of Administrative Law 229.

${ }^{100}$ A slight qualification is appropriate in relation to those jurisdictions with charters Victoria and the Australian Capital Territory. However, their significance should not be overstated, since they adopt the 'declaration of incompatibility' model rather than the 'power to declare invalid' model. These words are not words of limitation: Union Steamship Co of Australia Pty Ltd v King (1988) 166 CLR 1.

${ }^{101}$ Section 109 of the Commonwealth Constitution (conflict between a valid Commonwealth law and valid state law is resolved in favour of the former). Of course, it may also be inconsistent with state discrimination laws, but these are not doubly entrenched, and thus could be easily amended or repealed by a state parliament. Discussion of these laws appears in Margaret Thornton and Trish Luker, "The Spectral Ground: Religious Belief Discrimination' (2009) 9 Macquarie Law Journal 71; Reid Mortensen, 'Rendering to God 
9(1) of the Act makes it unlawful for a person to do an act involving a distinction or restriction based on race, colour, descent or national or ethnic origin $^{102}$ which has the purpose or effect of nullifying or impairing the enjoyment or exercise, on an equal footing, of any human right or fundamental freedom. ${ }^{103}$ Section 9(1A) applies where a person applies a requirement to another person that is not 'reasonable' having regard to the circumstances of the case, if the other person does not comply with it. The requirement must have the purpose or effect of impairing the equal enjoyment of a human right by those of the same colour, descent, national or ethnic origin as the complainant. Section 10 relevantly states that if by reason of a state law persons of a particular race, colour, national or ethnic origin ('first race') do not enjoy a right enjoyed by persons of another race, colour or national or ethnic origin ('second race'), then those of the first mentioned race enjoy the right to the same extent as those of the second race. In other words, the discrimination is overturned. ${ }^{104}$

While the Racial Discrimination Act 1975 (Cth) does not, on its terms, outlaw religious discrimination, religious discrimination may in effect be prohibited given the above references in s10 to 'ethnic origin'. Australian and United Kingdom precedents have confirmed that Jewish people can comprise an

and Caesar: Religion in Australian Discrimination Law' (1995) 18 University of Queensland Law Journal 208; Rachel Bloul, 'Anti-Discrimination Laws, Islamophobia and Ethnicization of Muslim Identities in Europe and Australia' (2008) 28(1) Journal of Muslim Minority Affairs 7; Anne Hewitt, 'It's Not Because You Wear Hijab, It's Because You're Muslim' Inconsistencies in South Australia's Discrimination Laws' (2007) 7(1) QUT Law and Justice Journal 57. Given the ease with which state discrimination laws could be amended, I do not discuss in detail individual differences between them in terms of racial/ethnic/religious discrimination.

102 This is of course similar to the wording of the Race Relations Act 1976 (UK) s 1(1A), implementing the European Directive 2000/43/EC.

103 The reference here to 'purpose or effect' picks up the wording of the International Convention on the Elimination on all Kinds of Racial Discrimination, and is broader than the High Court of Australia's current reading of s 116 of the Constitution, which requires a purpose of interfering with religious freedom.

104 There are key differences between the Australian discrimination provision and similar provisions in the United Kingdom; 1) The Australian legislation does not require that the complainant suffer a 'particular disadvantage' as does the Race Relations Act 1976 (UK) s 1(1A) and Equality Act 2010 (UK) s 19; 2) the Australian legislation does not allow discrimination to occur if it is a proportional means of achieving a legitimate end (by contrast with s 1(1A) of the Race Relations Act 1976 (UK) and s 19 of the Equality Act 2010 (UK)), and 3) the Australian Act does not distinguish between direct and indirect discrimination, as does the United Kingdom legislation. On the other hand, the scope of the Acts, being applied to race, colour, nationality, and ethnic or national origins, is similar. 
ethnic group for the purposes of the Racial Discrimination Act 1975 (Cth) ${ }^{105}$ and Race Relations Act 1976 (UK). ${ }^{106}$ It remains an open question in Australia whether followers of the Islamic faith constitute an 'ethnic group' within the meaning of the Racial Discrimination Act 1975 (Cth). ${ }^{107}$ The court considered the meaning of 'ethnic group' in Mandla $v$ Dowell-Lee, ${ }^{108}$ identifying characteristics such as (a) shared history of which the group was conscious as distinguishing it from other groups, and the memory of which it keeps alive; and (b) a cultural tradition of its own, including family and social customs and manners, often but not necessarily associated with religious observance.

In King-Ansell v Police, a New Zealand court found a group to be identifiable by its ethnic origin if it is a segment of the population distinguished from others by a sufficient combination of shared customs, beliefs, traditions and characteristics derived from a common or presumed common past, even if not drawn from common racial stock. The group would have a distinct social identity based not only on group cohesion and solidarity, but also beliefs as to their historical antecedents. ${ }^{109}$ Given this, it would be difficult to conclude

${ }^{105}$ Miller $v$ Wertheim [2002] FCAFC 156 [14]; see also Jones v Scully (2002) 120 FCR 243, 271-3; Silberberg $v$ The Builders Collective of Australia Inc [2007] FCA 1512 [22]. In the Jones case, the court noted that Jews saw themselves as a distinct community bound by common customs and beliefs, with a common language and sharing common characteristics [112].

${ }^{106} R v$ Governing Body of JFS [2009] UKSC 15 (I have acknowledged above the key differences between the Australian and United Kingdom discrimination legislation regimes).

${ }^{107}$ The Explanatory Memorandum to the Racial Hatred Act 1995 (Cth) states an intention that the concept 'ethnic origin' be applied to those of the Muslim faith: Explanatory Memorandum, Racial Hatred Bill 1994 (Cth), 2-3; however, some United Kingdom decisions suggest that Islam is not an 'ethnic origin' because although Muslim people profess a common belief system, followers are divided across many nations, colours and languages: Tariq v Young (Unreported, Employment Appeals Tribunal 24773/88), Nyazi v Rymans Limited (Unreported, Employment Appeals Tribunal 6/88). The New South Wales AntiDiscrimination Tribunal found that a Muslim follower did not have an 'ethno-religious' origin within that State's discrimination laws (Khan v Commissioner, Department of Corrective Services [2002] NSWADT 131 [21]. But see State of Queensland v Mahommed (2007) EOC 93-452 (Supreme Court of Queensland). Rachel Bloul criticises the distinctive treatment of Muslims here compared with, for example, the treatment of Jews and Sikhs, as 'ridiculously unjust but perfectly legal': 'Anti-Discrimination Laws, Islamophobia and Ethnicization of Muslim Identities in Europe and Australia' (2008) 28(1) Journal of Muslim Minority Affairs $7,7$.

${ }^{108}$ [1983] 2 AC 548, 569. The existence of a common geographical origin or descent from a smaller number of common ancestors, a common language, literature and religion, and the fact of being a minority or an oppressed or dominant group within a larger community also count (562).

${ }^{109}$ [1979] 2 NZLR 531, 543. Anthropological sources refer to self-perceived inclusion of those who hold in common a set of traditions not shared by others, often including religious beliefs and practices, language, a sense of historical continuity, and a common ancestry or place of 
that followers of Islam were not an ethnic group within the meaning of the Racial Discrimination Act 1975 (Cth). The above sources emphasise a common sense of beliefs, values and customs, clearly evident in followers of Islam with the five pillars ${ }^{110}$ and various other accepted practices. Clear links between religion-based bonds and ethnicity have been acknowledged in the literature above. It has been noted by Islamic scholars that Judaism and Islam are alike in many ways in terms of being monotheistic religions, ${ }^{111}$ as well as ritual and practice regarding food, attitude to statues and religious images. ${ }^{12}$ Given this fact, and the fact that precedent in both Australia and the United Kingdom confirms that Jews form an ethnic group, Muslims should not be excluded from the protection of the Racial Discrimination Act 1975 (Cth). Such legislation, being remedial in nature, should not be narrowly or pedantically applied. To do so would not be consistent with the purpose of the Act. ${ }^{113}$

Space does not allow a full airing of views here as to whether, if Muslim followers were an 'ethnic group' for the purposes of the RDA, a state law prohibiting the wearing of any face covering would be 'inconsistent' with the RDA in terms of section $109 .{ }^{114}$ The debate regarding whether the law must have a required purpose is easier here because the RDA specifically forbids a law with either a purpose or effect of discrimination based on ethnicity. If the law were cast as a ban on all face coverings, it might be argued the law does not breach section 9 of the RDA, because it does not distinguish between ethnicities, but applies to all. The argument might be that the effect of the law, while facially neutral, is that a Muslim cannot enjoy a right (expressed perhaps as a right to dress in accordance with their religion) enjoyed by person of other ethnicities (which ethnicity can be expressed through means

origin: Lola Romanucci-Ross, George A De Vos and Takeyuki Tsada, Ethnic Identity (Rowman Altamira, $4^{\text {th }}$ ed, 2006) 4-8.

110 These are: belief in God and that Muhammad is the messenger of God, prayer - Muslims must pray five times a day; fasting in the month of Ramadan; giving zakat or a percentage of one's yearly accumulated wealth to the poor and needy; and pilgrimage to Mecca: Jamila Hussain, Islam: Its Law and Society (Federation Press, 2 ${ }^{\text {nd }}$ ed, 2003) 14-15; David E Ingersoll, Richard K Matthews and Andrew Davison, The Philosophical Roots of Modern Ideology (Prentice Hall, $3^{\text {rd }} \mathrm{ed}$, 2001) 254. Although there are different interpretations of Islamic principles, 'there are several basic beliefs and values that hold the different Muslim interpretations of Islam together' (257).

${ }^{111}$ It is conceded that Christianity is also monotheistic, yet a Christian would not be considered to belong to a particular ethnic group by virtue of that fact.

${ }^{112}$ Hussain, above $\mathrm{n} 109,14$.

${ }^{113}$ Of course, where there is ambiguity, a court should lean to an interpretation of legislation that is consistent with its purpose or object: s $15 \mathrm{AB}$ Acts Interpretation Act 1901 (Cth). At common law the mischief rule of statutory interpretation applies.

${ }^{114} \mathrm{I}$ intend to explore the $\mathrm{s} 109$ issues in this context in detail in a future article. 
not involving the covering of the face, for argument's sake the wearing of a yarmulke), and as such the requirement breaches section 10 of the RDA.

\section{CONCLUSION}

If the Commonwealth Government passed a law (otherwise constitutional) banning the wearing of religious dress or symbols, the High Court should read the principle of religious freedom in section 116 broadly. It should not validate a law just because the Commonwealth argues the law was passed for other (legitimate) purposes; in some cases, it is submitted courts in other jurisdictions have been too willing to accept at face value government arguments that bans on religious dress or symbols were necessary in pursuit of legitimate objectives of equality and neutrality, or that effects on religious freedoms were incidental (and so not considered to be objectionable). While the precise meaning of the wearing of items such as the hijab or burqa is open to interpretation, on at least some interpretations such wearing is supported by the Qur'an; it is highly contentious to extrapolate from the wearing of such items of clothing that oppression, subjugation or 'extremism' is being reflected.

Such a ban might also infringe the Racial Discrimination Act 1975 (Cth); for a Commonwealth law, this is not significant since the Commonwealth can amend its own legislation; in relation to a state law which purported to implement a ban, the court would have to consider directly whether Islam followers are an 'ethnic group' within the meaning of the Act; and then whether a blanket state ban on all face covering would be inconsistent with the RDA, in particular section 10. There is a strong argument that Muslim followers do comprise an ethnic group, and that section 10 might be used to invalidate a state attempt to ban face covering, given its effect on those of Muslim 'ethnicity', compared with other ethnicities. 